\title{
Note on a Leptocephalus Stage of the Conger.
}

\author{
By
}

\author{
E. Ford, A.R.C.Sc.
}

Assistant Naturalist at the Plymouth Laboratory.

ON September 17th, 1919, a specimen of Leptocephalus Congri vulgaris (L. Morrisii) was captured in "bottom" haul No. 69 of the young fish trawl in locality Eddystone bearing $\mathrm{S}$. by W. (magnetic) $1 \frac{1}{2}$ miles, over a depth of 31 fathoms.* It was alive and active when taken, measuring between 115 and $120 \mathrm{~mm}$. in length, and has been kept alive up to the present date in a glass aquarium under circulation. It was at a fairly advanced stage of development, intermediate between those exhibited in Figs. 2 and 3, Pl. I of Schmidt (1), the dorsal fin commencing slightly farther back than in Fig. 3, and the median row of pigment spots along either side of the body not extending forward beyond about $1 \mathrm{~cm}$. in front of the commencement of the dorsal fin. There is a close resemblance also to the specimen figured by Fulton (2), with the exception that, as just pointed out, the median row of pigment along the body on either side does not reach forward quite to the head, and in addition the pigment spots at the base of the dorsal fin rays are only two or three in number, situated at the extreme posterior end of the fin.

Since the date of capture, observations have been made periodically and certain measurements taken as accurately as possible, but on account of the movements of the fish the latter could only be obtained approximately.

On October 5th, that is eighteen days after transference to its aquarium, the normal retrograde metamorphosis had resulted in a reduction in length to between 80 and $90 \mathrm{~mm}$., and its former "ribbon " shape was being superseded by the eel-like form, with a corresponding loss of transparency, while the dorsal fin had moved forward a considerable amount.

The pigmentation had intensified, and the upper surface throughout its whole length had become covered by a fairly uniform ground colouring. On the head this was quite dense, and reached down to about the level of the middle of the eye. On the body pre-anally it extended

* See page 181 of present volume of Journal. 
well down over the level of the vertebral column. The exact nature of this ground colouring could not be made out on the constantly moving specimen, but appeared to consist of very fine stellate closely set chromatophores. The air bladder was conspicuous and silvery. The vertebral column appeared to be very deeply pigmented along its dorsal surface. The median row of pigment spots along each side of the body had now extended forward completely to the head, and each of the rays of both dorsal and anal fins presented a pigment spot at its base. The additional pigment row above the one at the base of the anal fin was also clearly defined. The tail pigment had been augmented, and extended along the fin rays with a barred appearance distally. Blood vessels of reddish appearance were noticeable in the gills, along the dorsal surface of the alimentary canal, and post-anally immediately beneath the vertebral column to the extreme end of the body ; and in addition two smaller vessels of short length parallel to the main vessel were seen, one above and one below, at a point about $2 \mathrm{~cm}$. from the posterior end of the body with cross anastomosing connections.

On October 20th, the following body dimensions were noted as accurately as possible under the circumstances :-

$$
\begin{aligned}
& \text { Total length } \\
& \text { Pre-anal length } \\
& =\text { Between } 83 \text { and } 85 \mathrm{~mm} \text {. } \\
& \text { Distance from snout to commencement } \\
& \text { of dorsal fin } \\
& \text { Maximum depth (minus fins) } \\
& \text { Diameter of eye } \\
& \text { Pre-orbit } \\
& =\text { ca. } 29 \mathrm{~mm} \text {. } \\
& =\text { ca. } 15 \mathrm{~mm} \text {. } \\
& =\text { ca. } 5 \mathrm{~mm} \text {. } \\
& =\text { ca. } 2 \mathrm{~mm} \text {. } \\
& =\text { ca. } 3 \mathrm{~mm} \text {. }
\end{aligned}
$$

The dorsal fin had moved still farther forward, and the pectoral fins now reached back almost to its commencement. The latter had a band of pigment at their base and irregularly scattered stellate chromatophores along the rays. The nasal papillæ were well marked at this stage.

The ground colouring had now extended farther down the body to about three-quarters of its depth, while the under side of the body had become silvery. On the head the lower limit of the former was from the mouth to the lower edge of the eye, leaving the lower jaw and front portion of the operculum unpigmented. Both on the dorsal and anal fins, more especially on the former, pigment was present irregularly along the rays.

The fish is alive at the present date, and apparently in a healthy condition. It remains quiescent under some stones in its aquarium, and never leaves their shelter during the daytime unless made to do so, returning immediately after the disturbance has ceased. Although quantities of plankton, small amphipods, and pieces of finely chopped 
worm have been placed in the aquarium at intervals no attempt at feeding has been actually observed, but at night the fish exhibits more activity, moving over and around the stones.

Schmidt in his summary of the life-cycle of Conger vulgaris fixes the spawning period in spring and summer, with the metamorphosis in the following spring and summer. Our specimen which when captured had already begun its metamorphosis has since practically completed it, so that we may estimate the age at capture at certainly well over one year, with a possibility of eighteen months.

Summary of Captures Around British Isles.

\begin{tabular}{|c|c|c|c|c|c|c|c|}
\hline Area. & $\begin{array}{l}\text { Loncality of } \\
\text { Capture. }\end{array}$ & Identified by & $\begin{array}{c}\text { Year } \\
\text { of } \\
\text { Capture }\end{array}$ & $\begin{array}{c}\text { Month } \\
\text { of } \\
\text { Capture. }\end{array}$ & $\begin{array}{l}\text { No. } \\
\text { Speci- } \\
\text { mens. }\end{array}$ & $\begin{array}{c}\text { Length } \\
\text { of } \\
\text { Specimens. }\end{array}$ & $\begin{array}{l}\text { Depth over } \\
\text { which } \\
\text { Captured. }\end{array}$ \\
\hline Scotland & $\begin{array}{l}\text { Loch Scridain } \\
\text { Moray Firth } \\
\text { (South of } \\
\text { Smith Bank) } \\
\text { Smith Bank } \\
\text { (Moray Firth) } \\
\text { Aberdeen Bay } \\
\text { Orkneys and } \\
\text { Shetlands }\end{array}$ & $\begin{array}{l}\text { McIntosh } \\
\text { and } \\
\text { Masterman } \\
\text { Fulton } \\
\text { ", } \\
\text {," } \\
\text { Bowman }\end{array}$ & $\begin{array}{l}1890 \\
1903 ? \\
1903 ? \\
1904 \\
1911\end{array}$ & $\begin{array}{l}\text { Dec. } \\
\text { May } \\
\text { Aug. }\end{array}$ & $\begin{array}{l}1 \\
1 \\
1\end{array}$ & $\begin{array}{l}80 \mathrm{~mm} . \\
123 \mathrm{~mm} . \\
145 \mathrm{~mm} \text {. } \\
\text { ca. } 5 \mathrm{ins} \text {. } \\
128 \mathrm{~mm} \text {. }\end{array}$ & $\begin{array}{l}24 \text { fms. } \\
28 \mathrm{fms} . \\
4-5 \mathrm{fms} \text {. } \\
102 \text { metres }\end{array}$ \\
\hline Ireland & $\begin{array}{c}55^{\circ} \mathrm{N} .9^{\circ} \mathrm{W} \\
50^{\circ}-52^{\circ} \mathrm{N} \\
10^{\circ}-12^{\circ} \mathrm{W}\end{array}$ & $\begin{array}{c}\text { Schmidt } \\
, "\end{array}$ & $\begin{array}{l}1905 \\
1905 \\
1906 \\
1906 \\
1906\end{array}$ & $\begin{array}{l}\text { June } \\
\text { June } \\
\text { May } \\
\text { June- } \\
\text { Sept. }\end{array}$ & $\begin{array}{l}1 \\
5 \\
5 \\
5 \\
1\end{array}$ & $\begin{array}{l}137 \mathrm{~mm} . \\
113-135 \mathrm{~mm} \text {. } \\
112-154 \mathrm{~mm} \text {. } \\
130-158 \mathrm{~mm} \text {. }\end{array}$ & $\begin{array}{l}116 \mathrm{~m} . \\
960-1420 \mathrm{~m} . \\
75-1450 \mathrm{~m} . \\
475-2480 \mathrm{~m} . \\
1030 \mathrm{~m} .\end{array}$ \\
\hline $\begin{array}{l}\text { English } \\
\text { Channel }\end{array}$ & $\begin{array}{l}\text { Plymouth } \\
\text { Sound } \\
\text { Off Cape } \\
\text { Gris Nez } \\
\text { Between } \\
\text { Penlee Point } \\
\text { and Eddy- } \\
\text { stone } \\
\text { Eddystone, } \\
\text { bearing S. } \\
\text { by W.(mag.) } \\
1 \frac{1}{2} \text { miles }\end{array}$ & $\begin{array}{l}\text { Cunningham } \\
\text { Gilson } \\
\text { ?*(M.B.A. } \\
\text { Laboratory } \\
\text { Museum) } \\
\text { Clark }\end{array}$ & $\begin{array}{l}1895 \\
1898 \\
1906\end{array}$ & $\begin{array}{l}\text { July } \\
\text { May } \\
\text { March }\end{array}$ & $\begin{array}{l}1 \\
1 \\
1\end{array}$ & $\begin{array}{l}112.5 \mathrm{~mm} \text {. } \\
124 \mathrm{~mm} \text {. } \\
\text { ca. } 125 \mathrm{~mm} \text {. }\end{array}$ & $\begin{array}{l}\text { Between- } \\
\text { tide marks. } \\
25 \mathrm{fms} . \\
-\end{array}$ \\
\hline
\end{tabular}

The above summary does not include earlier specimens of which precise information is not available. Couch, for example, in " Fishes of British Islands, 1865," figures Leptocephalus Morrisii, and refers to its

* This specimen belonging to the M.B.A. Laboratory Museum at Plymouth does not appear to have been recorded previously. It was preserved in formalin originally, and labelled as having been ejected from the stomach of a mackerel, and brought in by a fisherman, but the length of the specimen was not recorded. The estimation of the latter, which is given above, was made in November, 1919. 
occurrence off the Cornish coast, while Cunningham in "Marketable Marine Fishes, 1896," makes reference to two specimens taken during the Irish survey.

\section{REFERENCES.}

1. Schmidt, 1909. " On the occurrence of Leptocephali (Larval Murænoids) in the Atlantic, West of Europe." Med. fra Komm. fur Havund. B. III, No. 6.

2. Fulton, 1903. "The young of the Conger." 22nd Scott. Fishery Report, III, 1903, No. viii. Ichthyological Note. Plate XVIII, Fig. 2. 